\title{
Combustion Characteristics of Tree Woods
}

\author{
Suryakant Chakradhari, Khageshwar Singh Patel ${ }^{*}$ \\ School of Studies in Environmental Science, Pt. Ravishankar Shukla University, Raipur, India \\ Email: "patelks_55@hotmail.com
}

Received 29 February 2016; accepted 9 May 2016; published 12 May 2016

Copyright (C) 2016 by authors and Scientific Research Publishing Inc.

This work is licensed under the Creative Commons Attribution International License (CC BY). http://creativecommons.org/licenses/by/4.0/

(c) (i) Open Access

\begin{abstract}
Biomass is a renewable energy source because sun energy is stored in the form of biomass which regrows over a relatively short period as compared to fossil fuel. The biomass on burning released energy with emission of carbon dioxide, volatile organic compounds, particulate matters and ash residue. The combustion characteristics of biomass depends on several factors of plants i.e. bulk density, moisture, organic matter and metal content. In this work, the combustion characteristics i.e. heat value, moisture, volatile matter and ash content as well as emission fluxes of particulate matters $\left(\mathrm{PM}_{10}\right)$ of trees grown in central India are described. The calorific value (CV) of 53 trees was ranged from $5190-8130 \mathrm{kcal} / \mathrm{kg}$ with mean value $(p=0.05)$ of $6380 \pm 170 \mathrm{kcal} / \mathrm{kg}$. Bahera tree showed the highest CV, $8130 \mathrm{kcal} / \mathrm{kg}$, and hence, it was chosen for the detailed studies.
\end{abstract}

\section{Keywords}

Tree, Heat Value, Moisture, Volatile Matter, Particulate Matter, Ash Residue

\section{Introduction}

Biomass contains stored energy which is a versatile fuel for energy and power generation in many countries [1] [2]. Wood remains the largest biomass energy source today and several different kinds of biomass, such as wood chips, corn, and some types of garbage, are used to produce electricity. The biomass is converted into liquid fuels called biofuels that can power cars, trucks, and tractors. Leftover food products like vegetable oils and animal fats can create biodiesel, while corn, sugarcane, and other plants can be fermented to produce ethanol. The combustion characteristics of trees in various parts of the world were reported [3]-[13]. The calorific value (CV) of the biomass depends on several physiological and climatic factors. However, the bio-power has environmental risks and may damage ecosystems, produce harmful air pollution, consume large amounts of water, and produce net global warming emissions [14]. In this work, the combustion characteristic of 53 topical trees (i.e. Amla, Amaltas, Asoka, Bachain, Badam, Bael, Bamboo, Babool, Bahera, Ber, Bija, Chhatim, Chironji, Dhawda, Dumar, Gandherwa, Goriar, Guava, Gulmohar, Harra, Haldu, Imli, Jamun, Jungle jalebi, Kadambh, Kahuaa,

*Corresponding author. 
Karanj, Karra, Kasahi, Khamar, Kumahi, Kusum, Mahua, Mango, Menda, Mithineem, Munga, Neem, Nilgiri, Palas, Ramphal, Sagwan, Saja, Sal, Salai, Samel, Seetaphal, Shisham, Siris, Shoe babool, Sonpatti, Tendu and Unjain) grown in Raipur area, CG, India is described in order for sustainable renewal energy demand of the country. Among them, the most energetic Bahera tree is described in the details.

\section{Materials and Methods}

\subsection{Collection of Tree Sample}

The Chhattisgarh state, central India is situated in Deccan bio-geographical area with rich in unique biological diversity. The forest of the State is extended over $\approx 5.5 \times 10^{4} \mathrm{~km}^{2}$ area. At least 1500 plants exist in this area. The tree species were identified by using physico-genetic characteristics prescribed in the literatures [15] [16]. The wood of 53 trees grown in Raipur area, capital, Chhattisgarh state, India $\left(21^{\circ} 15^{\prime} 0^{\prime \prime} \mathrm{N}, 81^{\circ} 37^{\prime} 48^{\prime \prime} \mathrm{E}\right)$ were collected manually in December, 2015 randomly. The different tree parts of the most energetic Bahera tree were collected for determining calorific value. They were dried in oven at $50^{\circ} \mathrm{C}$ for one day. All wood samples were crushed and sieved out particles of size $\leq 0.25 \mathrm{~mm}$.

\subsection{Determination of Bulk Density, Moisture, Calorific Value and Ash Residue}

The bulk density (BD) of the biomass affect significantly the heat value. The BD of the biomass was measured by the water replacement method [17]. A $50 \mathrm{~mL}$ pure water was taken into a 100-mL graduated cylinder. A $10 \mathrm{~g}$ of the sample was poured in the cylinder by noting the volume enhancement. The mass of the displaced water was calculated by multiply with water density at the particular working temperature.

The moisture content of the tree samples was analyzed by heating it at $105^{\circ} \mathrm{C} \pm 2^{\circ} \mathrm{C}$ for a period of 60 min. The ash content of the materials was determined by heating the sample at $600^{\circ} \mathrm{C}$ for $4 \mathrm{hr}$ [18].

The calorific value was determined experimentally using a Digital Microprocessor Based Bomb CalorimeterUTS 1.34, Advance Research Instruments Co, New Delhi as described in the literature. A 1.0 g of wood sample was weighed and placed in the combustion capsule. The sample was then lowered in the wire bomb head while the bomb head was on its support. A $10 \mathrm{~cm}$ long fuse wire was firmly fixed to the electrodes to facilitate complete combustion by adding $1 \mathrm{~mL}$ of water to the bomb cylinder and moistening the sealing ring of the bomb head. The bomb was carefully lowered into the cylinder with tightly closing the sealing ring. The oxygen gas was flowed into the combustion cylinder. The bomb cylinder was then lowered into the calorimeter bucket. The calorimeter cover was carefully placed and the thermometer bucket lowered. The power was then switched on to start the auto temperature adjustment and the stirring motor. The initial temperature was recorded after equilibrium attained i.e. after $5 \mathrm{~min}$. The bomb was then fired using the ignition switch. The bucket temperature i.e. final temperature was recorded after stabilization i.e. after $5 \mathrm{~min}$. The difference between the original length and the new length was multiplied by 0.335 to obtain the number of calories liberated by combustion of the fuse (fuse wire correction). For every sample, calorific value in kcal/kg was calculated using the following equation [19]:

$$
\mathrm{GCV}=\left[\{\mathrm{We} \cdot \Delta \mathrm{T}\}-\left\{\mathrm{W}_{1}(4.18)+\mathrm{W}_{2}(0.335)\right\}\right] / \mathrm{M}
$$

where, GCV, M, We, $\mathrm{W}_{1}, \mathrm{~W}_{2}$ and $\Delta \mathrm{T}$ represent gross calorific value of species (kcal/kg), weight of sample, water equivalent, weight of cotton thread, weight of fuse wire and rise in temperature, respectively.

The content of volatile compounds including moisture was analyzed by using a Mettler Thermogravimetric Analyzer-TG-DGA-2 at heating rate of $20^{\circ} \mathrm{C} / \mathrm{min}$.

\subsection{Emission Fluxes of Particulate Matters}

The flux of $\mathrm{PM}_{10}$ was determined by burning the Bahera sample in a closed chamber $\left(0.5 \times 0.5 \times 0.5 \mathrm{~m}^{3}\right)$ equipped with the exhaust fan and UC Davis (USA) portable air sampler in December, 2015. The PM $_{10}$ emitted in a closed chamber was collected over the weighted 47-mm quartz filter. The $\mathrm{PM}_{10}$ mass was weighted out, and the flux was evaluated by dividing the $\mathrm{PM}_{10}$ mass with amount of the material burnt.

\subsection{Segregation of Particulate Matters}

The Anderson sampler (1531-107B-G289X) with eight stage cartridge: $\mathrm{PM}_{10.0 \text { - 9.0 }}, \mathrm{PM}_{9.0-5.8}, \mathrm{PM}_{5.8-4.7}, \mathrm{PM}_{4.7-3.3}$, 
$\mathrm{PM}_{3.3-2.1}, \mathrm{PM}_{2.1-1.1}, \mathrm{PM}_{1.1-0.7}$ and $\mathrm{PM}_{0.7}$ was used for the collection of respirable particulate matters $\left(\mathrm{PM}_{10}\right)$ in the segregation modes. The sampler was run for $2 \mathrm{hr}$ during burning of Bahera tree sample in December, 2015. The mass of dried loaded and blank filters were weighted out.

\subsection{Analysis}

The $\mathrm{pH}$ value of ash extract was determined by the Hanna $\mathrm{pH}$ meter. The Dionex ion chromatography- 1100 was used for monitoring of anions and cations. The content of elemental carbon (EC) and organic carbon (OC) were determined by the thermal method.

The IBM SPSS Statistics 23 was used for the statistical and cluster analysis in the present work [20].

\section{Results and Discussion}

The combustion of biomass produces energy with emission of volatile materials and particulate matters by remaining left ash residue. The parameters i.e. bulk density (BD), moisture content (MC), volatile organic matter (VOCs), particulate matter (PM) and ash residue (AR) were measured.

\subsection{Combustion Characteristics}

The parameters i.e. color of wood dust, BD, MC and AR of 53 wood dusts is summarized in Table 1. The wood dust color was found to be of various different color as shown in Table 1. The BD is important parameter in the energy generation, as well as in pulp production where it influences the inflow of wood to a digester or to a refine. The value of BD of 53 wood dusts was ranged from $700-2500 \mathrm{~kg} / \mathrm{m}^{3}$ with mean value $(\mathrm{p}=0.05)$ of 1103 $\pm 82 \mathrm{~kg} / \mathrm{m}^{3}$. The highest BD of Kahua tree was observed as shown in Figure 1. The MC value of 53 wood dusts were ranged from $2.7 \%$ - 6.7\% with mean value ( $p=0.05$ ) of $4.9 \% \pm 0.3 \%$ as shown in Figure 2.

The calorific value (CV) of 53 tree samples was varied from $5193-8133 \mathrm{kcal} / \mathrm{kg}$ with mean value $(\mathrm{p}=0.05)$ of $6383 \pm 170 \mathrm{kcal} / \mathrm{kg}$ as shown in Table 1 . The Skew and Ku value of the data was found to be 0.50 and 0.29 , respectively. The positive skewness and kurtosis value indicated that data were found to skew right with moderate tailed distribution. The CV was found to be fairly positively and negatively correlated with the BD $(\mathrm{r}=$ $0.55)$ and MC $(r=-0.72)$ of the wood dust as shown in Figure 3. The CV value of tree woods of the present studied was found to be comparable to the heat value reported for trees of other regions of the country and the World [3]-[13].

The cluster analysis was carried out for grouping of CV of tree samples by using the BD, MC and AR as discriminating factor [20]. They were grouped into two clusters, Figure 4. The Cluster-I included 36 tree samples having lower CV. The Cluster-II was composed of 18 tree samples of Bahera, Ramphal, Ber, Tendu, Kusum, Mendra, Imli, Jamun, Palas, Seetaphal, Gandherwa, Mithineem, Neem, Bachain, Bija, Khamar, Kahua and Chhatim, having higher CV. The highest CV of Bahera wood dust was detected, may be due to higher content of the fixed carbon. Seven common trees i.e. Bahera, Ber, Imli, Kusum, Mendra, Ramphal and Tendu imparted the $\mathrm{CV}$ above $7000 \mathrm{kcal} / \mathrm{kg}$ as shown in Figure 6(a).

Bahera is a large deciduous tree found throughout India. The tree height was up to $30 \mathrm{~m}$, while the bark is brownish grey in color with leaves of $\approx 15 \mathrm{~cm}$ long and crowded toward the ends of the branches as shown in Figure 5. It contains $\beta$-sitosterol, gallic acid, ellagic acid, ethyl gallate, galloyl glucose and chebulagic acid, which render its therapeutic properties. The CV for different parts of the Baheratree was found to be comparable as shown in Figure 6(b).

The TG-DGA chromatogram scanned for the Bahera wood sample is shown in Figures 7. The pyrolytic decomposition of Bahera tree sample was occurred in four stages. In the first stage, a $7.4 \%$ weight loss over temperature range $50^{\circ} \mathrm{C}-100^{\circ} \mathrm{C}$ was seen, may be due evaporation of light volatile compounds including water. In second stage, a $1.9 \%$ weight loss over temperature range $100^{\circ} \mathrm{C}-200^{\circ} \mathrm{C}$ was marked, may be due evaporation of higher volatile compounds. In the third stage, a remarkable high weight loss of $58.7 \%$ over temperature range of $200^{\circ} \mathrm{C}-400^{\circ} \mathrm{C}$ was observed, may be due to decomposition of hemicellulose and cellulose materials. In the last stage, the large decomposition of lignin and non-volatile compounds (fixed carbon) over temperature range of $400^{\circ} \mathrm{C}-1000^{\circ} \mathrm{C}$ was observed.

\subsection{Particulate Matters}

The $\mathrm{PM}_{10}$ emission fluxes for Bahera tree $(\mathrm{n}=3)$ during burning period was found to be $2310 \pm 180 \mathrm{mg} / \mathrm{kg}$. The 
Table 1. Physical and combustion characteristics of wood

\begin{tabular}{|c|c|c|c|c|c|c|c|}
\hline S. No. & Local name & Botanical name & Color & $\mathrm{BD}, \mathrm{kg} / \mathrm{m}^{3}$ & MC, \% & $\mathrm{CV}, \mathrm{kcal} / \mathrm{kg}$ & AR, \% \\
\hline 1 & Chironji & Buchania lanzann & PW & 1100 & 4.3 & 6610 & 16 \\
\hline 2 & Mango & Mangifera indica L. & YW & 1000 & 5.1 & 6150 & 11 \\
\hline 3 & Ramphal & Annona reticulate & GrW & 1200 & 3.2 & 7230 & 13 \\
\hline 4 & Seetaphal & Annona squamosa & PY & 800 & 5.9 & 5190 & 16 \\
\hline 5 & Chhatim & Alstonia scolaris & $\mathrm{LGr}$ & 900 & 4.7 & 5700 & 12 \\
\hline 6 & Samel & Bombax ceiba & $\mathrm{Rd}$ & 1300 & 3.6 & 6750 & 10 \\
\hline 7 & Salai & Boswellia serrata & $\mathrm{DBr}$ & 1000 & 4.2 & 6350 & 11 \\
\hline 8 & Unjain & Celastru peniculata & $\mathrm{Br}$ & 1100 & 5.1 & 6160 & 9 \\
\hline 9 & Dhawda & Anogeissus latifolia & PY & 1000 & 4.7 & 6100 & 10 \\
\hline 10 & Kahua & Terminalia arjuna & $\mathrm{Br}$ & 2500 & 4.7 & 6790 & 9 \\
\hline 11 & Bahera & Terminalia bellirica & Gr & 1700 & 2.7 & 8130 & 8 \\
\hline 12 & Harra & Terminalia chebula & PY & 900 & 4.5 & 6440 & 14 \\
\hline 13 & Saja & Terminalia tomentosa & LB & 900 & 3.4 & 6580 & 10 \\
\hline 14 & Kusum & Carthamus tinctorius & LB & 1600 & 3.6 & 7530 & 9 \\
\hline 15 & Sal & Shorea robusta & $\mathrm{Rd}$ & 1700 & 4.4 & 6680 & 11 \\
\hline 16 & Tendu & Diospyrus melanoxylon & PY & 1400 & 3.6 & 7500 & 9 \\
\hline 17 & Karra & Cleistanthus collinus & Gr & 1100 & 5.1 & 6120 & 7.1 \\
\hline 18 & Amla & Embilica officinalis & PW & 1200 & 4.6 & 6710 & 11 \\
\hline 19 & Bija & Pterocarpus marsupium & $\mathrm{Rd}$ & 800 & 4.8 & 5720 & 14 \\
\hline 20 & Babool & Acacia nilotica & $\mathrm{DBr}$ & 800 & 5.6 & 6130 & 12 \\
\hline 21 & Goriar & Acacia caesia & PY & 900 & 5.8 & 6350 & 12 \\
\hline 22 & Siris & Albizzia lebbek & Gr & 1000 & 3.8 & 6670 & 8.1 \\
\hline 23 & Sonpatti & Bauhinia racemosa & $\mathrm{LBr}$ & 1100 & 5.8 & 6050 & 14 \\
\hline 24 & Palas & Butea monospermae & $\mathrm{LBr}$ & 700 & 6.1 & 5220 & 13 \\
\hline 25 & Amaltas & Cassia fistula & $\mathrm{LBr}$ & 1300 & 5.4 & 6120 & 13 \\
\hline 26 & Shisham & Dalbergia sissoo & $\mathrm{LBr}$ & 1200 & 3.8 & 6790 & 9 \\
\hline 27 & Gulmohar & Delonix regia & PY & 1100 & 5.7 & 5930 & 14 \\
\hline 28 & Munga & Erythrinia indica & Yw & 1300 & 5.5 & 6500 & 9 \\
\hline 29 & Shoe babool & Leucaena leucocephala & Yw & 700 & 5.6 & 6360 & 13 \\
\hline 30 & Jungle jalebi & Pithecolobium dulce & LY & 1000 & 5.5 & 6130 & 11 \\
\hline 31 & Karanj & Pongamia pinnata & Gr & 1500 & 5.8 & 6470 & 10 \\
\hline 32 & Gandherwa & Prosopis cineraria & LY & 1000 & 6.1 & 5490 & 13 \\
\hline 33 & Asoka & Saraca indica & Gr & 1200 & 6.1 & 6180 & 11 \\
\hline 34 & Imli & Tamarindus indica & LG & 1400 & 2.9 & 7450 & 8 \\
\hline 35 & Bamboo & Bombusa vulgaris & $\mathrm{PGr}$ & 1300 & 3.8 & 6940 & 11 \\
\hline
\end{tabular}




\section{Continued}

\begin{tabular}{|c|c|c|c|c|c|c|c|}
\hline 36 & Khamar & Gmelina arborea & PGr & 800 & 4.6 & 5700 & 13 \\
\hline 37 & Neem & Azadirachta indica & $\mathrm{Br}$ & 1000 & 6.4 & 5640 & 9 \\
\hline 38 & Bachain & Melia azadirachta & $\mathrm{W}$ & 1000 & 5.7 & 5720 & 14 \\
\hline 39 & Dumar & Ficus glomerata & $\mathrm{Br}$ & 800 & 6.1 & 5950 & 13 \\
\hline 40 & Kumahi & Careya arborea & Gr & 1000 & 6.7 & 6670 & 12 \\
\hline 41 & Nilgiri & Eucylaptus grandis & $\mathrm{Rd}$ & 1200 & 5.6 & 5970 & 14 \\
\hline 42 & Guava & Psidum guyava & LGr & 800 & 6.2 & 6450 & 13 \\
\hline 43 & Jamun & Syzygium cuminii & $\mathrm{Gr}$ & 1000 & 4.8 & 5310 & 12 \\
\hline 44 & Kasahi & Bridelia retusa & $\mathrm{DBr}$ & 800 & 5.8 & 6010 & 14 \\
\hline 45 & Badam & Prunus amygdalus & $\mathrm{CrW}$ & 1100 & 5.2 & 6220 & 13 \\
\hline 46 & Ber & Zizyphus mauritiana & $\mathrm{CrW}$ & 1200 & 3.2 & 7570 & 9 \\
\hline 47 & Haldu & Adina cordifolia & DY & 1000 & 6.7 & 6110 & 14 \\
\hline 48 & Kadambh & Anthocephalus cadamba & $\mathrm{Br}$ & 900 & 3.7 & 6620 & 11 \\
\hline 49 & Menda & Randia dumetorum & $\mathrm{Rd}$ & 1200 & 3.4 & 7480 & 9 \\
\hline 50 & Bael & Aegle marrmelos & PY & 950 & 5.4 & 6730 & 12 \\
\hline 51 & Mithineem & Murraya koenigii & $\mathrm{W}$ & 1000 & 4.8 & 5800 & 13 \\
\hline 52 & Mahua & Madhuca latifolia & PW & 1000 & 4.2 & 6940 & 10 \\
\hline 53 & Sagwan & Tectona grandis & $\mathrm{Br}$ & 1000 & 5.1 & 6170 & 13 \\
\hline
\end{tabular}

$\mathrm{Br}=$ Brown, $\mathrm{PW}=$ Pale white, $\mathrm{W}=$ White, $\mathrm{Rd}=$ Reddish, $\mathrm{DY}=$ Dark yellow, $\mathrm{CrW}=$ Cream white, $\mathrm{DBr}=\mathrm{Dark}$ brown, $\mathrm{Gr}=\mathrm{Greenish}, \mathrm{LGr}=\mathrm{Light}$ green, $\mathrm{Br}=$ Brown, Yellowish white $=$ YW.

$\mathrm{PM}_{10}$ was segregated into 8 modes i.e. $\mathrm{PM}_{10.0 \text { - 9.0 }}, \mathrm{PM}_{9.0-5.8}, \mathrm{PM}_{5.8 \text { - 4.7 }}, \mathrm{PM}_{4.7-3.3}, \mathrm{PM}_{3.3-2.1}, \mathrm{PM}_{2.1-1.1}, \mathrm{PM}_{1.1-0.7}$ and $\mathrm{PM}_{0.7-0.0}$ modes to know their distribution pattern. The highest fraction of the PM was found in the ultra fine mode as shown in Figure 8. The fraction of EC and OC in the $\mathrm{PM}_{10}$ was found to be $13 \pm 2$ and $64 \% \pm 3 \%$, respectively. Among ions, the highest content of $\mathrm{Cl}^{-}$followed by Ca was marked in the $\mathrm{PM}_{10}$ as presented in Figure 9. The large fraction of the PM was composed of the OC.

\subsection{Ash Residue}

The AR of woods influenced negatively $(r=-0.55)$ the heat value as shown in Figure 3 . The fraction of AR of 53 wood dusts was ranged from $7.1 \%-16 \%$ with mean value $(p=0.05)$ of $11.5 \% \pm 0.6 \%$ as shown in Figure 10 . The $\mathrm{pH}$ value of the ash extracts $(5.0 \mathrm{~g}$ ash residue was extracted with $25 \mathrm{~mL}$ of deionized water for $6 \mathrm{hr}$ in ultrasonic bath) was found to be alkaline in nature, ranging from $7.1-16.0$ with mean value $(p=0.05)$ of $11.5 \pm$ 0.6. The fraction ( $\mathrm{n}=3$ ) of EC, OC, $\mathrm{Cl}^{-}, \mathrm{SO}_{4}^{2-}, \mathrm{Na}, \mathrm{K}, \mathrm{Mg}$ and $\mathrm{Ca}$ of Bahera wood ash was found to be $7.6 \pm$ $0.8,0.7 \pm 0.2,6.4 \pm 0.9,5.2 \pm 0.8,1.8 \pm 0.5,6.3 \pm 1.4,2.2 \pm 0.2$ and $12.7 \% \pm 1.3 \%$, respectively.

\section{Conclusion}

The fast growing trees of wild nature i.e. Ber, Bahera, Imili, Kusum, Menda, Ramphal and Tendu are found to exhibit the higher $\mathrm{CV}>7000 \mathrm{kcal} / \mathrm{kg}$, may be due to their higher biomass productions and containing higher combustible carbons. Among 53 trees tested, the Bahera tree was observed to be the most energetic biomass in the present investigation. Five trees namely: Dhawda, Kauha, Bahera, Harra and Saja included in Combretaceae family are seemed to be energetic biomass to use as solid fuel instead of coal in the near future. 


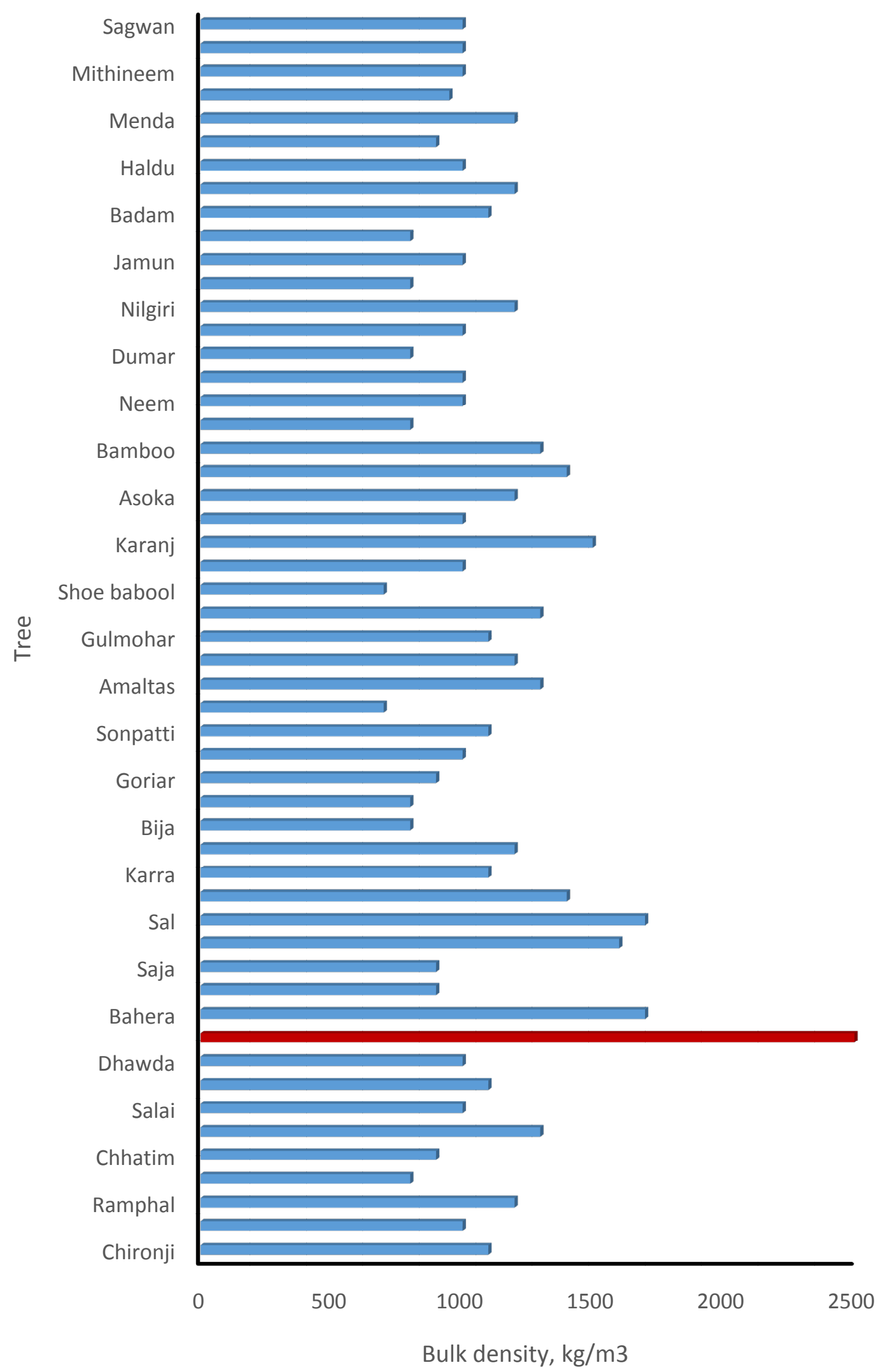

Figure 1. Bulk density of wood. 


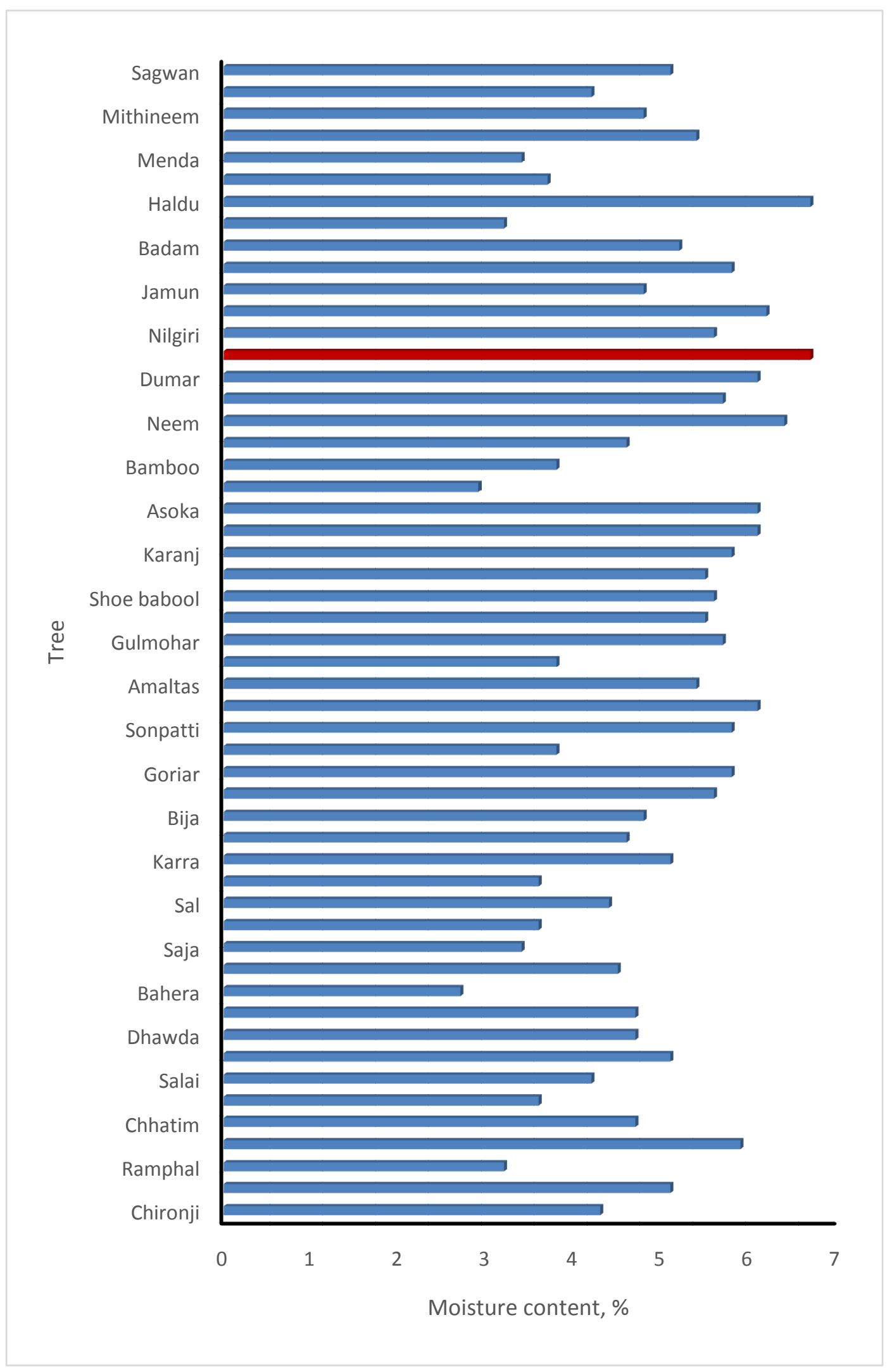

Figure 2. Moisture content of wood samples. 
(a)

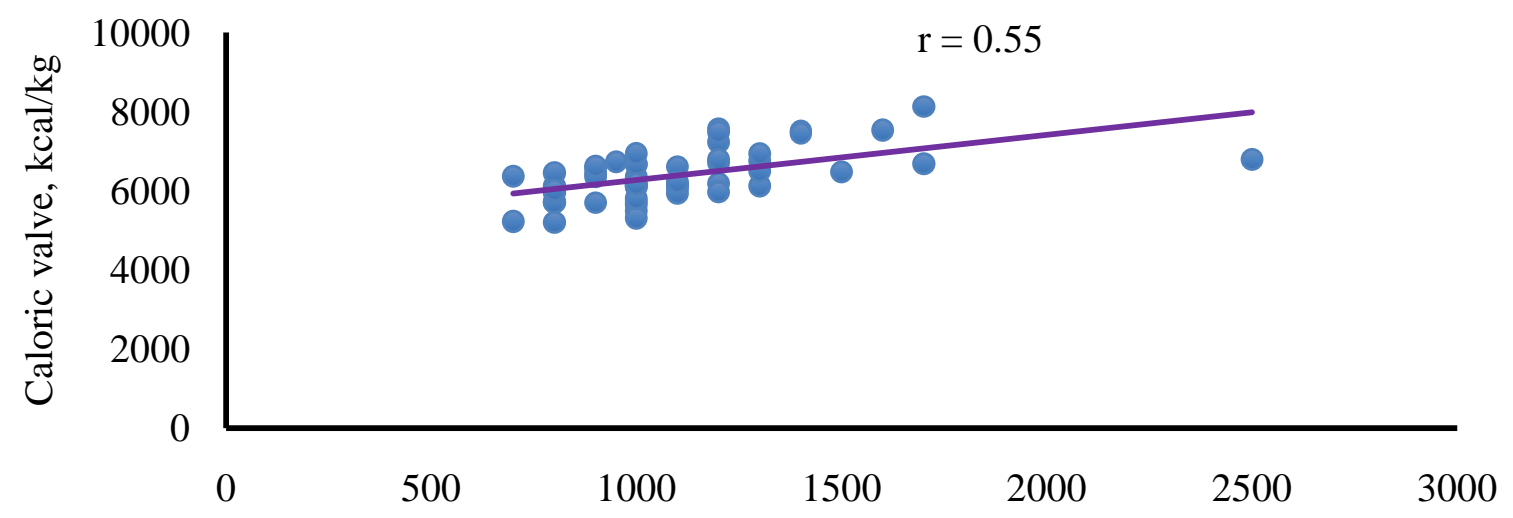

Bulk density, $\mathrm{kg} / \mathrm{m}^{3}$

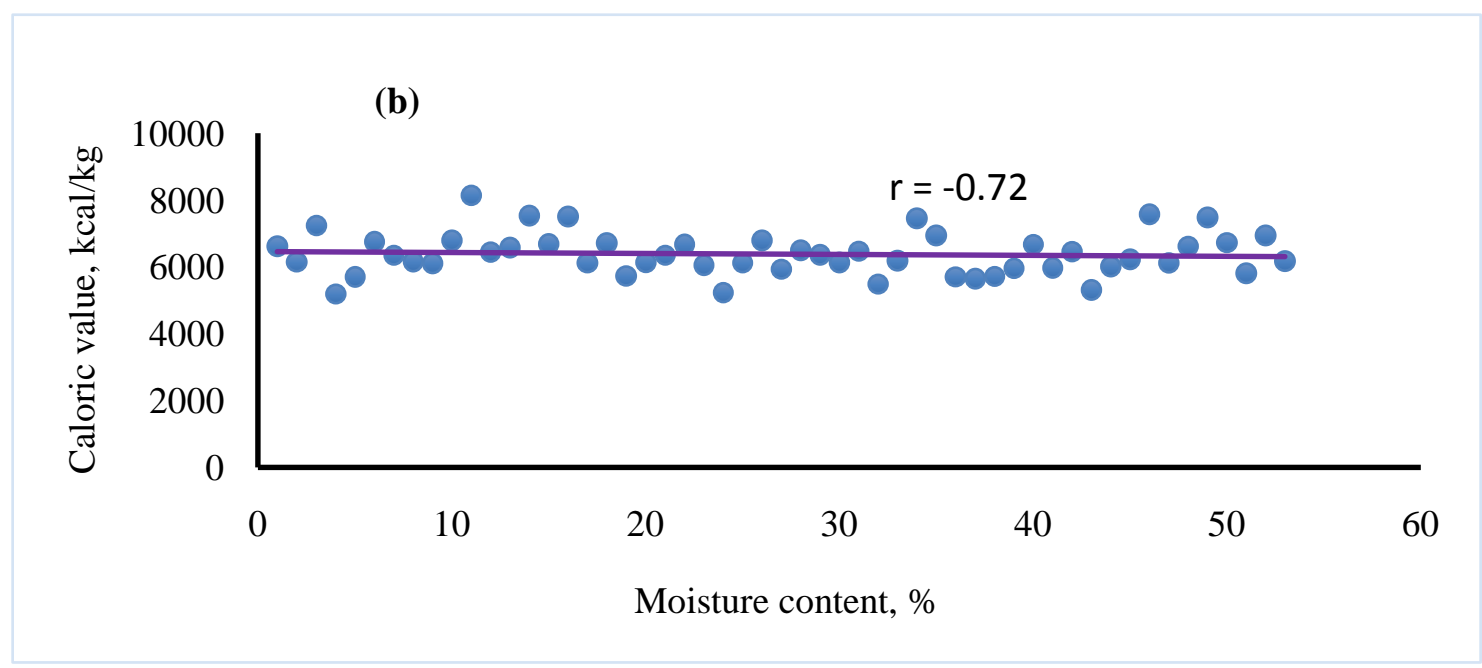

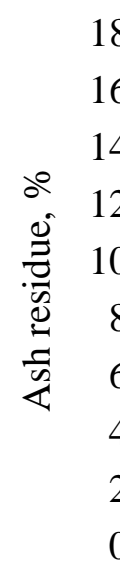

(c)

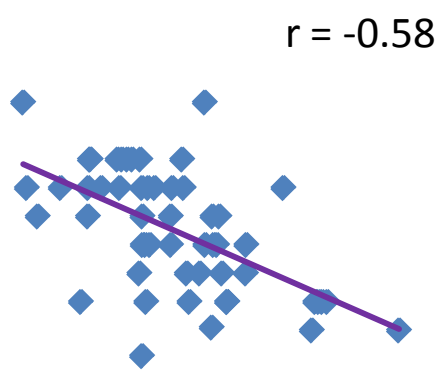

4
2
0

0

2000

4000

6000

8000

10000

Caloric value, $\mathrm{kcal} / \mathrm{kg}$

Figure 3. Correlation matrices of CV with bulk density (a), moisture (b) and ash residue (c). 


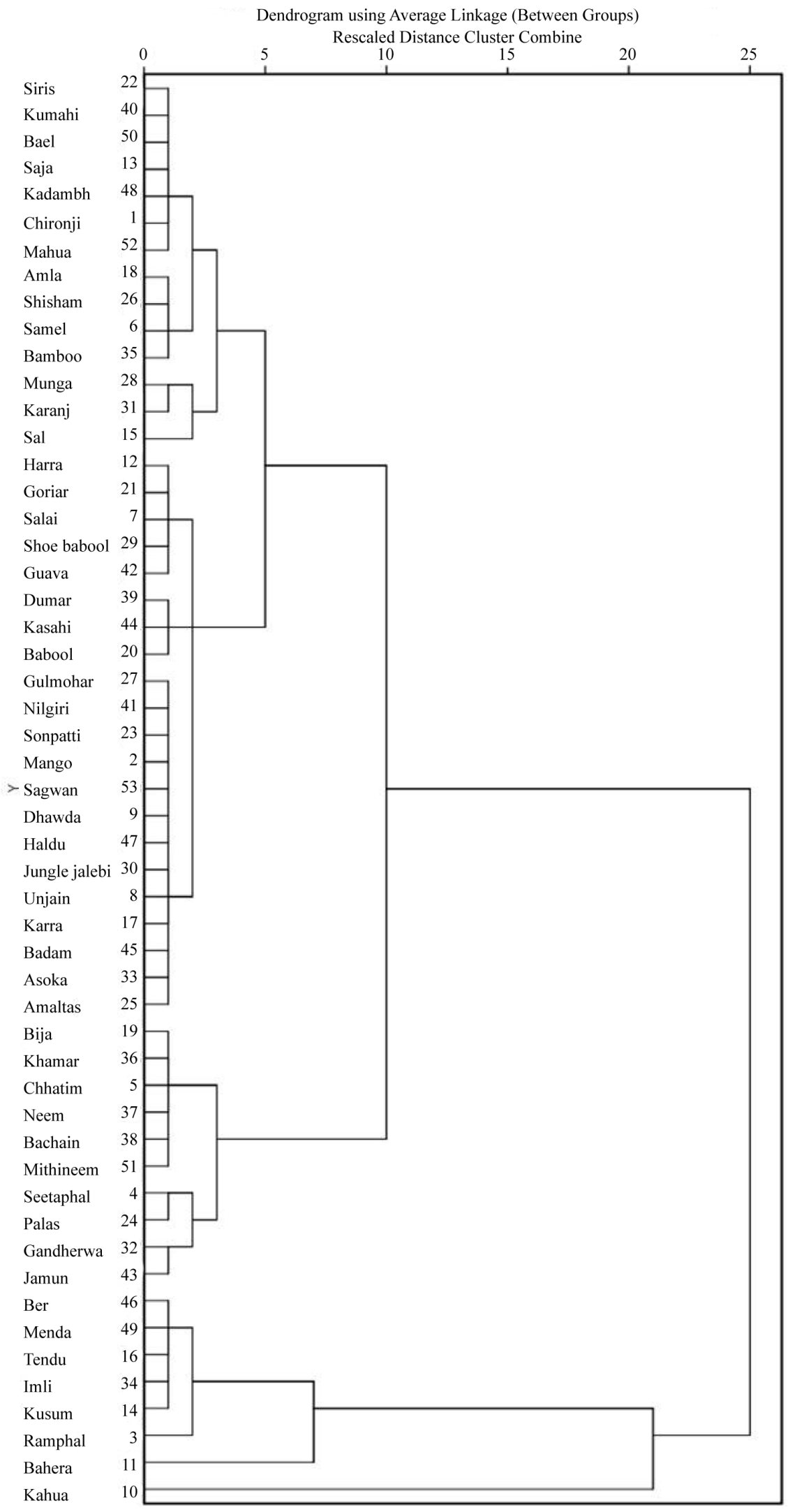

Figure 4. Dendrogram of calorific value of 53 wood samples. 


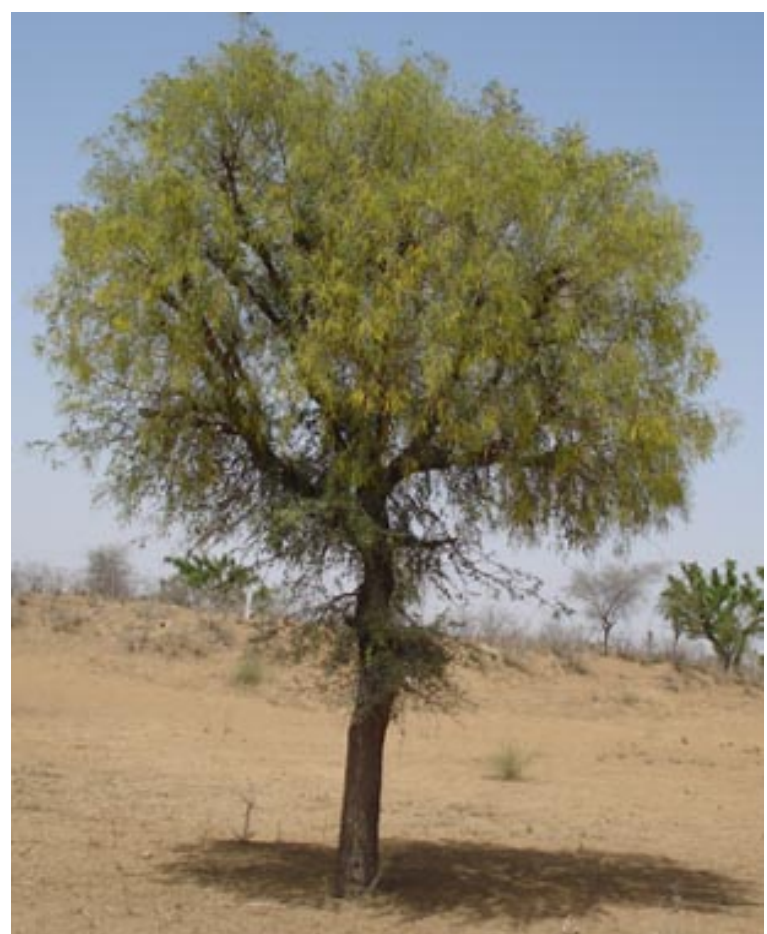

Figure 5. Bahera tree grown in University area, Raipur.
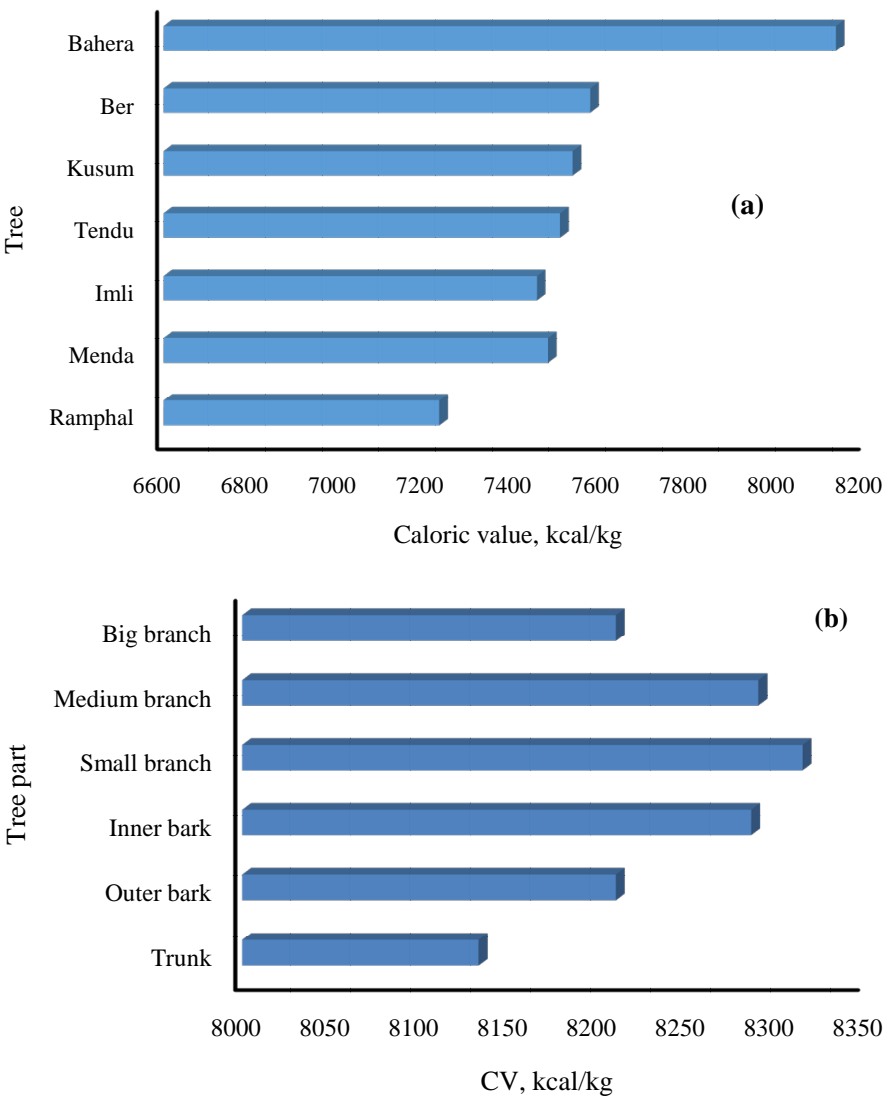

Figure 6. Calorific value of energetic trees and different parts of Bahera tree. 


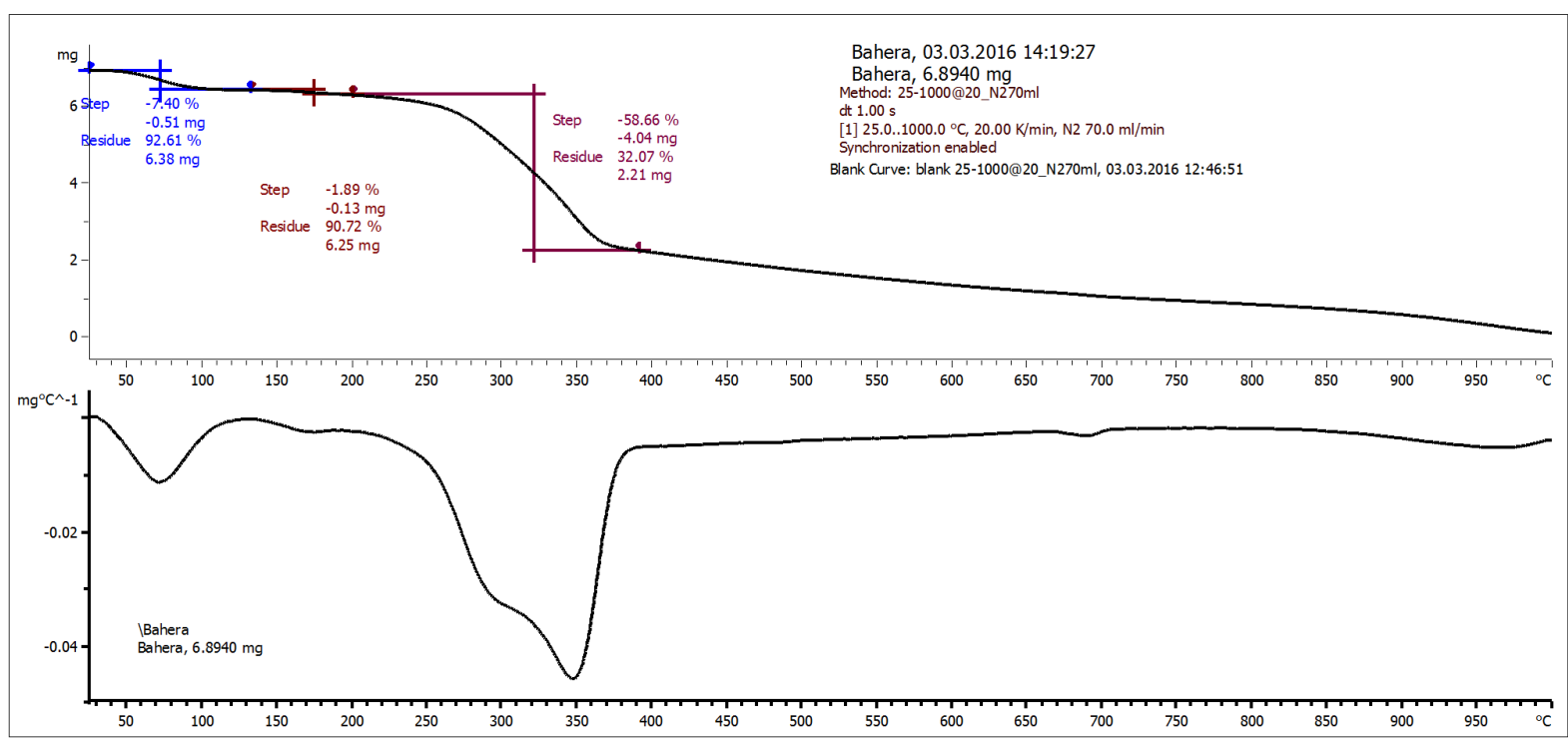

Figure 7. TG-DGA chromogram of Bahera wood dust.

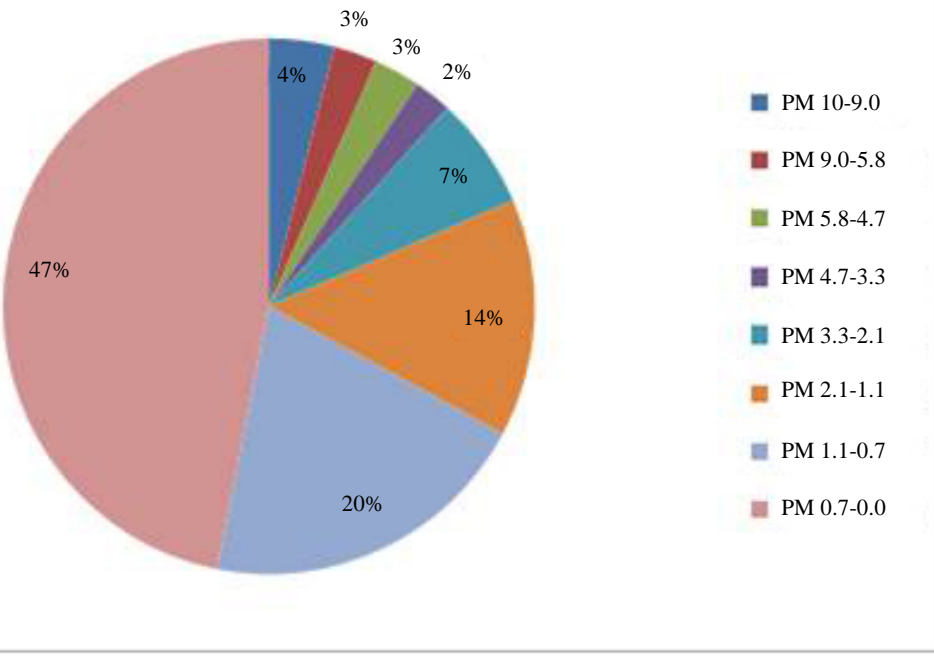

Figure 8. Segregation of $\mathrm{PM}_{10}$ of Bahera tree sample during combustion period.

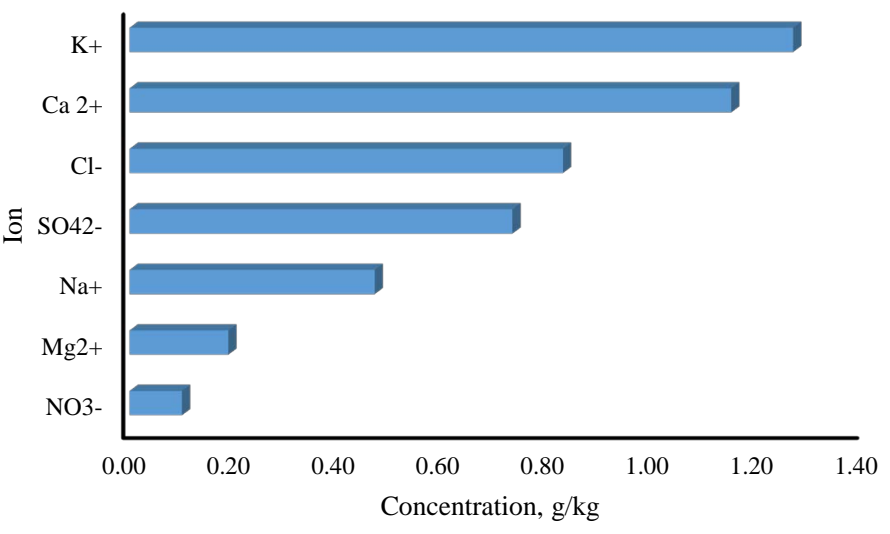

Figure 9. Fraction of ions in $\mathrm{PM}_{10}$ of the Bahera wood. 


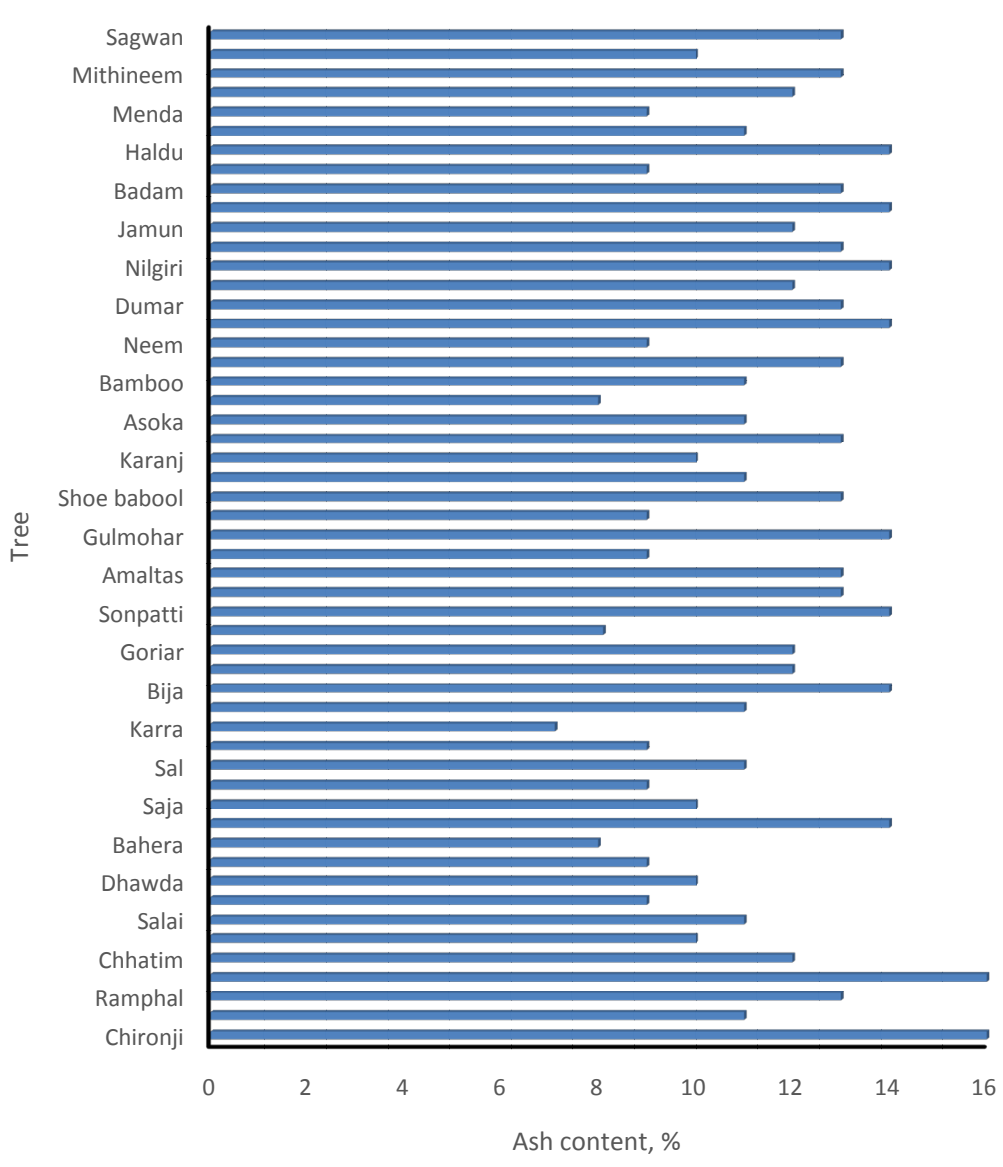

Figure 10. Ash residue fraction in wood samples.

\section{Acknowledgements}

We are thankful to our University for grating special equipment grant to the Environmental Science Department.

\section{References}

[1] IEA Bioenergy (2007) Potential Contribution of Bioenergy to the World’s Future Energy Demand, Rotorua, New Zealand. http://www.idahoforests.org/img/pdf/PotentialContribution.pdf

[2] Clini, C., Musu, I. and Gullino, M.L. (2010) Sustainable Development and Environmental Management: Experiences and Case Studies. Springer.

[3] Bhatt, B.P. and Tomar, J.M.S. (2002) Firewood Properties of Some Indian Mountain Tree and Shrub Species. Biomass and Bioenergy, 23, 257-260. http://dx.doi.org/10.1016/S0961-9534(02)00057-0

[4] Kumar, R., Pandey, K.K., Chandrashekar, N. and Mohan, S. (2011) Study of Age and Height Wise Variability on Calorific Value and Other Fuel Properties of EucalyptusHybrid, Acacia Auriculaeformis and Casuarina equisetifolia. Biomass and Bioenergy, 35, 1339-1344. http://dx.doi.org/10.1016/j.biombioe.2010.12.031

[5] Kataki, R. and Konwer, D. (2002) Fuelwood Characteristics of Indigenous Tree Species of North-East India. Biomass and Bioenergy, 22, 433-437. http://dx.doi.org/10.1016/S0961-9534(02)00026-0

[6] Khider, T.O. and Elsaki, O.T. (2012) Heat Value of Four Hard wood Species from Sudan. Journal of Forest Products \& Industries, 1, 5-9.

[7] Munalula, F. and Meincken, M. (2009) An Evaluation of South African Fuelwood with Regards to Calorific Value and Environmental Impact. Biomass and Bioenergy, 33, 415-420. http://dx.doi.org/10.1016/j.biombioe.2008.08.011

[8] Telmo, C. and Lousada, J. (2011) Heating Values of Wood Pellets from Different Species. Biomass and Bioenergy, 35, 2634-2639. http://dx.doi.org/10.1016/j.biombioe.2011.02.043

[9] Tietema, T., Ditlhogo, M., Tibone, C. and Mathalaza, N. (1991) Characteristics of Eight Firewood Species of Botswa- 
na. Biomass and Bioenergy, 1, 41-46. http://dx.doi.org/10.1016/0961-9534(91)90050-M

[10] Mitchual, S.J., Frimpong-Mensah, K. and Darkwa, N.A. (2014) Evaluation of Fuel Properties of Six Tropical Hardwood Timber Species for Briquettes. Journal of Sustainable Bioenergy Systems, 4, 1-9. http://dx.doi.org/10.4236/jsbs.2014.41001

[11] Turinawe, H., Mugabi, P. and Tweheyo, M. (2014) Density, Calorific Value and Cleavage Strength of Selected Hybrid Eucalypts Grown in Uganda. Maderas: Ciencia y Tecnología, 16, 13-24.

[12] Aniszewska, M. and Gendek, A. (2014) Comparison of Heat of Combustion and Calorific Value of the Cones and Wood of Selected Forest Trees Species. Leśne Prace Badawcze, 75, 231-236. http://dx.doi.org/10.2478/frp-2014-0022

[13] Björn, G., Gebauer, K., Barkowski, R., Rosenthal, M. and Bues, C.T. (2012) Calorific Value of Selected Wood Species and Wood Products. European Journal of Wood and Wood Products, 70, 755-757. http://dx.doi.org/10.1007/s00107-012-0613-z

[14] Sagar, A.D. and Kartha, S. (2007) Bioenergy and Sustainable Development? Annual Review of Environment and Resources, 32, 131-167.

[15] Hocking, D. (1993) Trees for Drylands. Oxford \& IBH Publishing Co Pvt. Ltd., New Delhi.

[16] Gupta, A.K. (2003) Quality Standards of Indian Medicinal Plants. Vol. I, ICMR, New Delhi.

[17] ASTM International (2008) ASTM Standard D2395-2007a: Standard Test Methods for Specific Gravity of Wood and Wood-Based Materials. ASTM International, West Conshohocken.

[18] ASTM International (2008) ASTM D 1102-84, Test Method for Ash in Wood. Annual Book of ASTM Standards, 153-154.

[19] ASTM D5865 - 13 (2013) Standard Test Method for Gross Calorific Value of Coal and Coke, ASTM International, West Conshohocken, PA. www.astm.org

[20] IBM SPSS Statistics 23 (2015). http://www-01.ibm.com/support/docview.wss?uid=swg21698495 